\title{
Wax Ester Hydrolysis by Lipolytic Enzymes in Pyloric Caeca of Various Fishes
}

\author{
Mitsumasa Mankura, ${ }^{* 1}$ Mitsu Kayama, ${ }^{* 1}$ and Shigeru SAITO ${ }^{* 1,2}$
}

(Accepted May 14, 1984)

\begin{abstract}
The wax ester hydrolase activities in liver, hepatopancreas, intestine and pyloric caecum of chub mackerel, blue drum, brown sole, flat fish, yellowtail, red sea bream and black sea bream were compared with the lipase and esterase activities. The lipase activity of pyloric caecum was the highest in all tissues used. In the case of esterase, its activity was remarkable in liver or hepatopancreas of yellowtail and black sea bream, and in pyloric caeca of blue drum and brown sole. Wax ester hydrolysis occurred in almost all the tissues and its hydrolase activity in pyloric caecum of chub mackerel was rather high. The results indicate that wax ester hydrolase activity of the fishes which prey on marine organisms containing more amounts of wax esters was noticeable. Pyloric caeca, as a source of lipolytic enzymes, play an important role on wax ester metabolism in the same way as liver, hepatopancreas and intestine.
\end{abstract}

Wax esters are the major lipid class in copepods that form a major part of the diet of a variety of commercially important fish including anchovy, sardines, pilchards, sprats, herring, menhaden, argentines, makerel, young blue whiting and young salmon. To digest the wax esters their pyloric caeca, which are the characteristic tissue in aquatic animals, would play an important role in addition to other guts.

Although lipase and esterase in liver (or hepatopancreas) and intestine of various fishes have been studied so far, ${ }^{1-7)}$ it is not clear that these enzymes could actually hydrolyze wax esters or not as one of the lipolytic enzymes. A few studies have been performed on the hydrolysis of wax esters with pyloric caeca preparations. ${ }^{4,8-8)}$ BENSON et al. ${ }^{87}$ studied the hydrolysis of wax esters which are important as one of the energy sources in marine organisms, and found that the preparations from pyloric caeca of chum salmon, anchovy and jack mackerel hydrolyzed polyunsaturated $\mathrm{C}_{18}$-alkyl $\left[{ }^{3} \mathrm{H}\right]$-oleate as well as $\left[{ }^{14} \mathrm{C}\right]$-triolein and cholesteryl oleate. The authors $\left.{ }^{7}, 10,11\right)$ also investigated the hydrolysis and synthesis of wax esters in digestive organs of carp, and insisted on the importance of plasma enzyme on the syntheses of wax esters and cholesterol esters.

In the present paper, we deal with the distribution of lipolytic enzymes such as lipase, esterase and wax ester hydrolase in some marine fishes, and describe the differences of lipolytic enzymes between active and sessile fishes.

\section{Materials and Methods}

\section{Animals and Treatment}

Fish species used as lipolytic enzyme source are chub mackerel Scomber japonicus, blue drum Nibea mitsukurii, brown sole Limanda herzensteini, flat fish Paralichthys olivaceus, yellowtail Seriola quinqueradiata, red sea bream Pagrus major, and black sea bream Acanthopagrus schlegeli. Immediately after obtaining fish in the fresh condition from a fish dealer, its liver or hepatopancreas, intestine, and pyloric caeca were homogenized separately for $5 \mathrm{~min}$ in ice-cooled teflon homogenizer with two volumes of $0.05 \mathrm{M}$ potassium phosphate buffer $(\mathrm{pH} \mathrm{8.0)}$. The homogenates were centrifuged for $10 \mathrm{~min}$ at $10,000 \times \mathrm{g}$ and $2^{\circ} \mathrm{C}$, and the supernatants were used as crude enzyme sources.

\section{Assay of Lipase and Esterase}

Ediol (Calbiochem Co.) was used as a substrate for lipase activity, and methyl butyrate (Wako Pure Chemical Ind.) for esterase activity according to the method of OKUDA and FumI. ${ }^{12}$ The enzymatic assay was carried out as described in our pre-

*1 Laboratory of Marine Biochemistry, Faculty of Applied Biological Science, Hiroshima University, Fukuyama 720, Japan (万合三正・鹿山 光・少藤 滋：広島大学生物生産学部水族生化学研究室).

*2 Present Address: Yaizu Suisan Kagaku Industries Co., Ltd., Yaizu 425, Japan（焼津水座化学工業株式 会社). 
(1) Preparation of Enzyme Solution

$$
\text { Tomogenization in ice-cooled homogenizer (5 min) }
$$

(2) Measurement of Enzyme Activities* Reaction mixture for lipase Ediol $5 \%$ bovine albumin in $0.05 \mathrm{M}$ K-phosphate buffer ( $\mathrm{pH} 8.0) \quad 0.45 \mathrm{~m} l$ $0.05 \mathrm{ml}$

Reaction mixture for esterase Enzyme solution Total volume $0.5 \mathrm{~m} l$
$1.0 \mathrm{~m} l$
Methyl butyrate 0.05 м K-phosphate buffer (pH 8.0)

Enzyme solution
$50 \mu \mathrm{mol}$

$0.45 \mathrm{~m} l$

Total volume

$0.5 \mathrm{~m} l$

$1.0 \mathrm{~m} l$.

Incubation at $35^{\circ} \mathrm{C}$ for $60 \mathrm{~min}$

$$
\downarrow
$$

Stop the reaction by the addition of DoLE's extraction mixture $(5 \mathrm{~m} l)$

$\downarrow$

Titration by $0.01 \mathrm{~N} \mathrm{NaOH}$ solution in $90 \%$ ethanol

Fig. 1. Lipase and Esterase Assay. ${ }^{7}{ }^{13)}$

* Lipase activity is expressed as $\mu \mathrm{eq} / \mathrm{m} / / \mathrm{mg}$ protein on the basis of oleic acid, and esterase

\begin{tabular}{|c|c|}
\hline Cetyl $\left[1-{ }^{14} \mathrm{Clpalmitate}\right.$ & $\mu \mathrm{mol}$ \\
\hline Triton X-100 & $5 \mathrm{mg}$ \\
\hline Na-taurochorate & $1.5 \mathrm{mg}$ \\
\hline Enzyme solution & $1.0 \mathrm{ml}$ \\
\hline
\end{tabular}
as $\mu \mathrm{mol} / \mathrm{m} l / \mathrm{mg}$ protein on the basis of butyric acid.

(1) Preparation of Enzyme Solution

$\begin{array}{ll}\text { Tissue } & 1 \\ 0.05 \mathrm{M} \text { K-phosphate buffer (pH 8.0) } & 2 \\ \text { Homogenization in ice-cooled homogenizer } \quad(5 \mathrm{~min}) \\ \downarrow \\ \text { Centrifugation at } 10,000 \times g \text { for } 10 \mathrm{~min} \quad\left(2^{\circ} \mathrm{C}\right)\end{array}$

(2) Measurement of Enzyme Activity*

Reaction mixture

Stop the reaction by the addition of chloroform-methanol (2:1) extraction mixture $(3.0 \mathrm{ml})$

$$
\text { Separation of lipid classes by TLC plate }
$$

Fig. 2. Assay for wax ester hydrolyzing enzyme, ${ }^{7,13}$

* Wax ester hydrolyzing activity is expressed as percentage of the released radioactivity from cetyl [1-14 C]palmitate.

vious papers. ${ }^{7,13)}$ The details of assay are shown in Fig. 1. The lipase activity is expressed as $\mu \mathrm{eq} /$ $\mathrm{m} / / \mathrm{mg}$ protein on the basis of oleic acid and the esterase as $\mu \mathrm{mol} / \mathrm{m} l / \mathrm{mg}$ protein on the basis of butyric acid.
Assay for Wax Ester Hydrolyzing Enzyme Cetyl $\left[1{ }^{14} \mathrm{C}\right]$ palmitate $(0.5 \mu \mathrm{Ci}, 50 \mu \mathrm{mol})$ was used as a substrate for wax ester hydrolyzing enzyme. The contents in the reaction mixture are as shown in Fig. 2. After incubating it for $60 \mathrm{~min}$ 
at $35^{\circ} \mathrm{C}$, the reaction was stopped by adding chloroform-methanol (2:1) mixture. Total lipids were extracted by the modified method of BLIGH and DYER. ${ }^{14)}$ Lipid analysis and radioactivity counting were conducted as described in the previous papers. ${ }^{7,13}$ The activity is expressed as percentage of the released radioactivity from cetyl $\left[1{ }^{-14} \mathrm{C}\right]$ palmitate.

\section{Determination of Protein}

Protein content was measured by the method of LOWRY et al. ${ }^{13)}$

\section{Results}

Comparison of Lipase Activities in Various Fishes Lipase activities of liver(hepatopancreas), intestine, and pyloric caecum in various fishes are shown in Table 1. Generally speaking, lipase activities in pyloric caeca were higher than liver or hepatopancreas and intestine, and those of blue drum and brown sole were seemed to be relatively high, but those of young yellowtails were low. The differences of lipase activities between the fishes moving actively in the sea such as chub mackerel or yellowtail and the fishes moving dully such as flat fish, brown sole, red sea bream or black sea bream

Table 1. Lipase activities in liver or hepatopancreas, intestine and pyloric caecum in various fishes

\begin{tabular}{|c|c|c|c|c|}
\hline \multirow[b]{2}{*}{ Fish Species*1 } & & \multicolumn{3}{|c|}{ Tissues } \\
\hline & & $\begin{array}{c}\text { Liver*2 or } \\
\text { Hepatopancreas*3 }\end{array}$ & Intestine & $\begin{array}{l}\text { Pyloric } \\
\text { caecum }\end{array}$ \\
\hline Chub Mackerel & & tr.*2 & 11.10 & tr. \\
\hline Blue Drum & & $13.17^{* 3}$ & 2.15 & 19.20 \\
\hline Brown Sole & & tr.*3 & tr. & 16.49 \\
\hline Flat Fish & & $2.27^{* 3}$ & 3.41 & 4.18 \\
\hline Young Yellowtail & 1 & $2.88^{* 2}$ & 2.83 & 6.34 \\
\hline " & 2 & $1.84^{* 2}$ & 0.79 & 0.37 \\
\hline " & 3 & $2.25 * 2$ & 2.66 & 3.95 \\
\hline Red Sea Bream & 1 & $1.91 * 3$ & 0.66 & 2.87 \\
\hline " & 2 & $1.66^{* 3}$ & 1.74 & 4.70 \\
\hline Black Sea Bream & 1 & $11.89^{* 3}$ & tr. & tr. \\
\hline 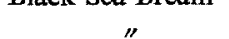 & 2 & $6.51^{* 3}$ & tr. & tr. \\
\hline
\end{tabular}

Lipase activities are expressed as $\mu \mathrm{eq} / \mathrm{m} / \mathrm{mg}$ protein

*1 Fish species used are chub mackerel Scomber japonicus, blue drum Nibed mitsukurit, brown sole Limanda herzensteini, flat fish Paralichthys olivaceus, yellowtail Seriola quinqueradiate, red sea bream Pagrus major, and black sea bream Acanthopagrus schlegeli.

Table 2. Esterase activities in liver or hepatopancreas, intestine and pyloric caeca in various fishes

\begin{tabular}{|c|c|c|c|c|}
\hline \multirow[b]{2}{*}{ Fish Species*i } & & \multicolumn{3}{|c|}{ Tissues } \\
\hline & & $\begin{array}{c}\text { Liver }^{* 2} \text { or } \\
\text { Hepatopancreas }\end{array}$ & Intestine & $\begin{array}{l}\text { Pyloric } \\
\text { caecum }\end{array}$ \\
\hline Chub Mackerel & & $1.52 * 2$ & tr. & tr. \\
\hline Blue Drum & & $\operatorname{tr}{ }^{* 3}$ & tr. & 9.09 \\
\hline Brown Sole & & $7.41 * 3$ & 23.59 & 26.01 \\
\hline Flat Fish & & $\operatorname{tr} .^{* 3}$ & 2.45 & 1.60 \\
\hline Young Yellowtail & 1 & $2.16^{* 2}$ & 1.83 & 0.90 \\
\hline " & 2 & $11.43 * 2$ & 0.91 & 0.17 \\
\hline " & 3 & $2.53^{* 2}$ & tr. & 1.71 \\
\hline Red Sea Bream & 1 & $4.35^{* 3}$ & 0.60 & 2.25 \\
\hline " & 2 & $4.07^{* 3}$ & 0.73 & 4.59 \\
\hline Black Sea Bream & 1 & $19.81^{* 3}$ & tr. & tr. \\
\hline " & 2 & $26.14^{* 3}$ & tr. & tr. \\
\hline
\end{tabular}

Esterase activities are expressed as $\mu \mathrm{mol} / \mathrm{m} / / \mathrm{mg}$ protein * 1 Fish species used are as Table 1 . 
Table 3. Wax ester hydrolyzing activities in liver or hepatopancreas, intestine and pyloric caecum in various fishes

\begin{tabular}{|c|c|c|c|c|}
\hline \multirow{2}{*}{ Fish Species ${ }^{* 1}$} & & \multicolumn{3}{|c|}{ Tissues } \\
\hline & & $\begin{array}{c}\text { Liver*2 }^{* 2} \text { or } \\
\text { Hepatopancreas }\end{array}$ & Intestine & $\begin{array}{l}\text { Pyloric } \\
\text { caecum }\end{array}$ \\
\hline Chub Mackerel & 1 & $1.1^{* 2}$ & 2.0 & 3.5 \\
\hline$"$ & 2 & $2.7 * 2$ & tr. & 4.4 \\
\hline$"$ & 3 & $\operatorname{tr} * 2$ & tr. & tr. \\
\hline Blue Drum & & $2.6^{* 3}$ & tr. & tr. \\
\hline Brown Sole & & tr..$^{* 3}$ & tr. & $\operatorname{tr}$. \\
\hline Flat Fish & & $4.7 * 3$ & 2.4 & tr. \\
\hline Yellowtail & & $\operatorname{tr} . * 2$ & 3.9 & tr. \\
\hline Young Yellowtail & 1 & $2.2^{* 2}$ & tr. & $\operatorname{tr}$. \\
\hline$"$ & 2 & $2.0^{* 2}$ & 2.4 & 1.4 \\
\hline " & 3 & $2.2^{* 2}$ & 2.1 & 3.9 \\
\hline Red Sea Bream & 1 & $13.5^{* 3}$ & 2.0 & tr. \\
\hline " & 2 & $7.1 * 3$ & tr. & tr. \\
\hline Black Sea Bream & 1 & $9.9 * 3$ & tr. & tr. \\
\hline & 2 & $1.5^{* 3}$ & tr. & 2.4 \\
\hline
\end{tabular}

Wax ester hydrolyzing activities are expressed as percentage of the released radioactivity from cetyl $\left[1{ }^{14} \mathrm{C}\right] p$ almitate. *1 Fish species used are as Table 1.

were not extremely remarkable.

\section{Comparison of Esterase Activities in Various Fishes}

Though esterase activity was rather higher than lipase activity as shown in Table 2 , the distribution of esterase in various fishes was similar to that of lipase. Especially the esterase activities in pyloric caeca of blue drum and brown sole were high. Those of sessil fishes like chub mackerel, flat fish, red sea bream and black sea bream were seemed to be relatively low in general.

\section{Comparison of Wax Ester Hydrolyzing Activities in Various Fishes}

Some fishes had wax ester hydrolyzing enzyme in pyloric caecum as well as in liver, hepatopancreas and intestine as shown in Table 3 , but its distribution did not coincide with the case of lipase and esterase. The activities in pyloric caeca of chub mackerel and yellowtail were rather higher, but those of sessil fishes such as brown sole, flat fish, red sea bream and black sea bream were low.

\section{Discussion}

So far many authors ${ }^{1-7,18-18)}$ described the activities of esterase and lipase of aquatic animals, however, the reports discussed on the distribution of lipolytic enzymes, especially wax ester hydrolase in pylolic caecum are very few as far as we know. Lipolytic enzymes of fishes exist not only in liver, hepatopancreas and intestine, but also in pyloric
Table 4. The numbers of pyloric caeca in various fish species

\begin{tabular}{lc}
\hline Fish Species & Numbers of Pyloric caeca \\
\hline Chub Mackerel & $80-130$ \\
Brown Sole & $8-10$ \\
Flat Fish & 4 \\
(Young) Yellowtail & $120-200$ \\
Red Sea Bream & 4 \\
Black Sea Bream & 4 \\
\hline
\end{tabular}

The numbers were counted before the determinations of enzymatic activities.

caecum. As shown in Table 4, there is a close correlation between the number of pyloric caecum and the lipolytic enzyme activities like lipase or esterase. And it is assumed that the fishes moving more actively in the sea have much more pyloric caeca and less intestine. Therefore, in the case of fishes with many pyloric caeca, the tissue seemed to play particularly more important role in wax ester hydrolysis than other tissues such as liver, hepatopancreas and intestine.

The results show that the lipolytic enzyme activity of active-moving fishes like chub mackerel and yellowtail with prominent pyloric caeca is higher than that of dull-moving fishes like fiat fish, brown sole, blue drum, red sea bream and black sea bream with inconspicuous pyloric caeca.

Benson et al. ${ }^{\text {s) }}$ described the reason that adult salmon serum contains very high levels of cholesterol ester, up to seventy times the level normal for human serum high density lipoproteins(HDL). 
It is caused by the action of a fatty acyl transferase which transfers acyl moiety from wax to cholesterol, because labelled cholesterol ester in serum lipoproteins appears after feeding $\left[{ }^{14} \mathrm{C}\right]$-labelled wax ester. Though we did not deal with the conversion of wax esters to cholesterol esters in plasma lipoprotein in the present work, it is suggested that the role of pyloric caeca on lipolytic metabolism is also rather important, particularly, from the aspect of wax ester hydrolysis.

It may be possible that the specificity of lipolytic enzymes would vary with the number of unsaturated bonds on the way of lipid transport. To understand the results as a whole, it needs the informations on polyene phosphatidylcholine metabolism in fish plasma. ${ }^{20)}$ Thus further study on the relation between phospholipids metabolism and lipolytic enzyme in fish plasma will be required.

\section{Acknowledgements}

We wish to express our thanks to Professor $M$. TAKAHASHI of Fuculty of Applied Biological Science, Hiroshima University, for valuable suggestions on the fish physiology.

\section{References}

1) L. C. Chesley: Biol. Bull. Mar. Biol. Lab., Woods Hole, 66, 133-144 (1934).

2) K. Shmada: Bull. Japan. Soc. Sci. Fish., 4, 914 (1935).

3) Y. SueHiro: Jap. J. Zool., 10, 1-303 (1941).

4) M. KtTamkado and A. Tatsuno: Bull. Japan. Soc. Sci. Fish., 26, 691-694 (1960).

5) J. S. Patton, J. C. Nevenzel, and A. A. Benson: Lipids, 10, 575-583 (1975).
6) J. S. Patton and A. A. Benson: Comp. Biochem. Physiol., 52B, 111-116 (1975).

7) M. Kayama, M. Mankura, and Y. Ikeda: $J$. Biochem., 85, 1-6 (1979).

8) A. A. Benson, R. F. Lee, and J. C. Nevenzel: Biochem. Soc. Symp. (Cambridge, Engl.), No. 35, 175-187 (1973).

9) J. R. Sargent, R. F. Lee, and J. C. Nevenzel: in "Chemistry and Biochemistry of Natural Waxes" (ed. by P. E. KolatTukUdx), Elsevier, Amsterdam, 1976, pp. 49-91.

10) M. Kayama, M. Mankura, and Y. Ikeda: Yukagaku (J. Jap. Oil Chem. Soc.), 28, 26-30 (1979).

11) M. Mankura and M. Kayama: in "Nonglyceride-lipids of Marine Animals" (ed. by Japan. Soc. Sci. Fish.), Kohseishakohseikaku, Tokyo, 1982, pp. 116-130.

12) H. OKuDA and S. FuJrr: J. Biochem., 64, 377385 (1968).

13) M. KaYama and M. MankuRa: Bull. Japan. Soc. Sci. Fish., 46, 1501-1505 (1980).

14) E. G. Bligh and W. F. Dyer: Can. J. Biochem. Pysiol., 37, 911-917 (1959).

15) O. H. Lowly, N. J. Rosebrough, A. L. Farr, and R. J. RANDALl: J. Biol. Chem., 193, 265275 (1951).

16) G. J. Ridgway, S. W. Sherburne, and R. D. LEwIs: Trans. Amer. Fish. Soc., 99, 147-151 (1970).

17) B. Bilnnskt, R. E. E. Jonas, and Y. C. LAU: $J$. Fish. Res. Board Can., 28, 1015-1018 (1971).

18) J. S. Patton: Lipids, 10, 562-564 (1975).

19) A. A. Benson, J.S. Patton, and C. E. Field: Comp. Biochem. Physiol., 52B, 339-340 (1975).

20) J. M. Fox: in "Phospholipids and Atherosclerosis" (ed. by P. E. Avogaro, M. Mancini, G. Ricci, and R. Paoletti), Raven Press, New York, 1983, pp. 65-80. 